\title{
Hepatoprotective Essential Oils: A Review
}

\author{
Nour Elhouda Daoudi, Mohamed Bnouham*
}

Laboratory of Bioressources, Biotechnology, Ethnopharmacology and Health, Department of Biology, Faculty of Sciences, University Mohamed Ist, Oujda, Morocco

Received December 22, 2018

Reviewed June 25, 2020

Accepted August 28, 2020

* Correspondence

Mohamed Bnouham

Laboratory of Bioressources,

Biotechnology, Ethnopharmacology and

Health, Department of Biology, Faculty

of Sciences, University Mohamed Ist,

Oujda, Morocco

Tel: +00212667627496

E-mail: mbnouham@yahoo.fr
Objectives: Several toxins and molecules are able to damage the liver, causing the hepato-toxicity. This disorder can be protected naturally, by some essential oils obtained from different plants. In this review we are cited some of these compounds that have been tested by their hepatoprotective effect.

Methods: We reviewed 83 articles published between 1981 and 2018 in English via three databases Sciencedirect, Springer and PubMed. So, we have used the keywords: Hepatoprotective effect, liver disease, plants and essential oils.

Results and conclusion: In this work, we classified the plants; contain the essential oils, in alphabetical order as a table containing the scientific, family names, information plants, the experimental assay and the results obtained from the hepatoprotective studies. We have described 27 species belonging to 12 families: Lamiaceae ( 7 species), Asteraceae (6 species), Umbellifereae (3 species), Apiaceae (3 species) are the main families which enclose the species that was studied. The study also includes the major compounds isolated from some of these essential oils. The most of those compounds belong to terpene class essentially cineol, carvacrol and thymol. Thus, the different essential oils that have been cited in this review were shown that have an antioxidant activity.

Keywords: hepatoprotective effect, essential oils, medicinal plants, hepatotoxic agents

\section{INTRODUCTION}

Essential oils are natural compounds obtained from aromatic herbs and characterized by a strong smell. They are volatile and complex components, mostly obtained by hydro-distillation or steam method that was developed by Arabs in the middle ages. Currently, there are 300 essential oils commercially in different applications: Pharmaceutical, cosmetic, perfume, agronomic and food [1]. They have been used for their beneficial properties such as insecticidal, [2] antibacterial [3] and antifungal activities [4].

Some essential plant oils are used to treat and manage different diseases as well as the liver damages. Indeed, many researches were done on certain of these oils, reported that these components have a hepatoprotective action. So, in this paper, we have cited some of these essential oils, referencing back to the various works that have been published in three databases: Sciencedirect, Springer and PubMed.

\section{MATERIALS AND METHODS}

In this paper, we included 83 works published between 1981 and 2018 in English, collected from Sciencedirect, Springer and PubMed databases. To find these publications, we have used the following keywords: Hepatoprotective effect/activity, liver disease, plants and essential oils. Therefore, 23 articles based on experimental studies of some plant essential oils against hepatotoxicity actions were included in this review.

\section{RESULTS}

In the present work, we classified the plants in the form of the table (Table 1) contains the scientific, family names, plants information and even the experimental assay and the results obtained from the hepatoprotective studies. 
Table 1. Hepatoprotective essential oils

\begin{tabular}{|c|c|c|c|c|}
\hline $\begin{array}{c}\text { Scientific } \\
\text { names }\end{array}$ & $\begin{array}{l}\text { Family } \\
\text { names }\end{array}$ & Plant information & Experimental assay & Active compounds \\
\hline $\begin{array}{l}\text { Achillea } \\
\text { biebersteinii } \\
\text { Afan }\end{array}$ & Asteraceae & $\begin{array}{l}\text { The countries around the } \\
\text { Mediterranean Sea and the } \\
\text { Arabian Peninsula are the native } \\
\text { origin of } A \text {. biebersteinii, which is } \\
\text { a perennial plant, characterized } \\
\text { by } 30 \text { to } 60 \mathrm{~cm} \text { in high. This } \\
\text { herb used traditionally to treat } \\
\text { abdominal pain, wound healing } \\
\text { and liver diseases like jaundice. }\end{array}$ & $\begin{array}{l}\text { The protective effect of the essential oil } \\
\text { obtained from the aerial parts of } A \text {. } \\
\text { biebersteinii has been evaluated; using } \\
\text { carbon tetra-chloride }\left(\mathrm{CCl}_{4}\right) \text { at a dose of } \\
1.25 \mathrm{~mL} / \mathrm{kg} \text { induced hepatotoxicity in } \\
\text { Wistar albino rats. Then, the liver was } \\
\text { dissected to perform the biochemical and } \\
\text { histological examination. } \\
\text { The results showed that the administration } \\
\text { of the essential oils at a dose of 0,2 mL/ } \\
\text { kg has a significant hepatoprotective } \\
\text { activity against CCl } \text { induced liver damage }_{\text {compared with control. Furthermore, the }} \\
\text { biochemical assay indicated that this } \\
\text { oil contains: } 56.3 \% \text { of the monoterpene } \\
\text { hydrocarbons, } 29.2 \% \text { of the monoterpene } \\
\text { hydrocarbons alfa-terpinene, } 22.9 \% \\
\text { p-cymene, } 4.7 \% \text { terpinen-4-ol, } 4.3 \% \text { of 1,8- } \\
\text { cineole, 3.9\% of trans-p-menth-2-en-1- } \\
\text { ol, 3.1\% of the ascaridole, } 2.5 \% \text { of trans- } \\
\text { piperitone oxide and } 2.1 \% \text { carvacrol [7]. }\end{array}$ & $\begin{array}{l}\text { Monoterpene hydrocarbons, } \\
\alpha \text {-terpinene, } p \text {-cymene, } \\
\text { oxygenated monoterpenes } \\
\text { of the total oil, terpinen- } \\
\text { 4-ol, 1,8- cineole, trans-p- } \\
\text { menth-2-en-1-ol, ascaridole, } \\
\text { trans-piperitone oxide and } \\
\text { carvacrol (7) }\end{array}$ \\
\hline $\begin{array}{l}\text { Achillea } \\
\quad \text { wilhelmsii }\end{array}$ & Asteraceae & $\begin{array}{l}\text { A. wilhelmsii used extensively } \\
\text { in Iran as a medicinal herb to } \\
\text { treat a lot of health problems. } \\
\text { It has an anti-oxidant, anti- } \\
\text { microbial, anti-hypertensive, } \\
\text { anti-hyperlipidemia and } \\
\text { immunomodulatory effects [8- } \\
\text { 11] }\end{array}$ & $\begin{array}{l}\text { The hepatoprotective activity of the essential } \\
\text { oils obtained from the aerial parts of this } \\
\text { plant was evaluated on acetaminophen } \\
\text { induced liver disorders in Wistar rats, } \\
\text { "by increasing of oxidative stress and } \\
\text { free radicals". Five hundred mg/kg of } \\
\text { the acetaminophen and the essential } \\
\text { oils at two different doses (100 and } 200 \\
\text { mg/kg) were injected intraperitoneally } \\
\text { in animals. Then, superoxide dismutase } \\
\text { (SOD), catalase (CAT), glutathione (GSH), } \\
\text { the ferric reducing ability of plasma (FRAP), } \\
\text { and lipid peroxidation (LPO) parameters } \\
\text { were measured after the treatment in } 2,4 \text {, } \\
8,16 \text { and } 24 \text { hours. } \\
\text { The experiment results showed that } \\
\text { acetaminophen treatments increased the } \\
\text { levels of SOD, LPO, and FRAP with the } \\
\text { diminishing of GSH level. Furthermore, the } \\
\text { treatment with A. wilhelmsii oils at doses } \\
100 \text { and } 200 \text { mg/kg with acetaminophen } \\
\text { restored significantly the GSH and reduced } \\
\text { the rise of SOD, LPO, and FRAP levels as } \\
\text { compared with the control. To confirm } \\
\text { the finding results, the histo-phatological } \\
\text { examination was carried out by using } \\
\text { small portions of the liver that showed the } \\
\text { presence of the hepatic necrosis inhibited } \\
\text { by the essential oils [12]. }\end{array}$ & $\begin{array}{l}\text { p-ocimen, 1,8 cineole, } \\
\text { carvone, camphor, and } \\
\text { verbanol acetate (13). }\end{array}$ \\
\hline
\end{tabular}


Table 1. Continued 1

\begin{tabular}{|c|c|c|c|c|}
\hline $\begin{array}{c}\text { Scientific } \\
\text { names }\end{array}$ & $\begin{array}{l}\text { Family } \\
\text { names }\end{array}$ & Plant information & Experimental assay & Active compounds \\
\hline Ajuga iva & Lamiaceae & $\begin{array}{l}\text { A. iva is an annual herbaceous } \\
\text { herb. It has several beneficial } \\
\text { effects, particularly in } \\
\text { gastrointestinal problems, } \\
\text { hypertension and diabetes [13]. }\end{array}$ & $\begin{array}{l}\text { The essential oils obtained from the air- } \\
\text { dried aerial parts of this plant were } \\
\text { evaluated by their hepatoprotective effect } \\
\text { at a dose of } 50 \mathrm{mg} / \mathrm{kg} \text { body weight on } 5 \\
\mathrm{~mL} / \mathrm{kg} \text { of } \mathrm{CCl}_{4} \text { inducing liver damage. The } \\
\text { tested oil was administered every day for } \\
\text { two weeks before the injection of } \mathrm{CCl}_{4} \\
\text { "intraperitoneally". Then, the chemical } \\
\text { composition of } A \text {. iva oils was defined by } \\
\text { gas chromatography associated to mass } \\
\text { spectrometry "GC-MS". The results of the } \\
\text { experiment indicated that the essential } \\
\text { oil of } A \text {. iva possesses a hepatoprotective } \\
\text { activity which may be explicated by their } \\
\text { antioxydant activity. Besides, there are } \\
48 \text { compounds that were identified in this } \\
\text { plant, representing } 99.40 \% \text { of the total oil } \\
\text { profile, with } 35.07 \% \text { of carvacrol [14]. }\end{array}$ & $\begin{array}{l}\text { 1,8- Cineole, linalool, camphor, } \\
\text { borneol, terpinene-4-ol, } \\
\text { methyl chavicol, carvone, } \\
\text { carvotanaceton, Z- anethol, } \\
\text { thymol, carvacrol, trans- } \\
\text { carvyl acetate (15). }\end{array}$ \\
\hline $\begin{array}{l}\text { Anethum } \\
\text { graveolens L. }\end{array}$ & Apiaceae & $\begin{array}{l}\text { A. graveolens } L \text {. is an annual } \\
\text { plant that used traditionally to } \\
\text { treat different diseases and it } \\
\text { is used too, as a condiment. } \\
\text { South-eastern Europe and } \\
\text { Mediterranean countries are } \\
\text { the native land of this plant } \\
\text { [15]. Moreover, it has been } \\
\text { declared by Heamalatha and al } \\
\text { in } 2011 \text { that } A \text {. graveolens had } \\
\text { antispasmodic, antibacterial, } \\
\text { antiulcer, diuretic, hypo-lipidemic } \\
\text { and antioxidant activities [16]. }\end{array}$ & $\begin{array}{l}\text { The evaluation of the protective effect of } \\
\text { the plant essential oils obtained from the } \\
\text { seeds part against } \mathrm{CCl}_{4} \text { was carried out } \\
\text { by using two groups of male albino rats. } \\
\text { The first one was kept as a control ( } \mathrm{n}= \\
6 \text { ) and the second one had received for } \\
\text { two weeks (twice a week) } 2 \mathrm{~mL} / \mathrm{Kg} \text { of } \mathrm{CCl}_{4} \\
\text { inducing chronic liver damage. Then, the } \\
\text { last group were divided into subgroups ( } \mathrm{n} \\
\text { = } 6 \text { each): Positive control and the treated } \\
\text { group which had received orally } 1 \text { mL/ } \\
\text { Kg of } A \text {. graveolens essential oils for four } \\
\text { weeks. } \\
\text { The results showed that the essential oil had } \\
\text { a potent hepatoprotective activity against } \\
\text { CCl } \mathrm{I}_{4} \text {. It is able to inhibe the hepato-toxicity } \\
\text { produced by CCl }{ }_{4} \text {. In fact, the experiment } \\
\text { showed that the treatment with this oil } \\
\text { decreased significantly AST and ALT levels. } \\
\text { However, it increased the total protein } \\
\text { and albumin levels. The main compounds } \\
\text { of the essential oil of this plant are } \\
\text { carvacrol, carvone, limonene, } p \text {-cymen, } \\
\text { dihydrocarvone, } \alpha \text {-phellandrene, and dill } \\
\text { apiole [15]. }\end{array}$ & $\begin{array}{l}\text { Carvacrol, carvone, limonene, } \\
\text { p-cymene, dihydrocarvone, } \\
\alpha \text {-phellandrene, and dill } \\
\text { apiole (16). }\end{array}$ \\
\hline
\end{tabular}

\section{DISCUSSION}

Liver tissue can be attacked by different toxins and molecules taken in overdoses which lead to dysfunction of this organ that is considered necessary for human life. However, there is some of natural product such as essential oils that are able to manage this disorder.

Liver injury was distinguished by many tests as the identification of ALT, ALP, bilirubin and AST levels [5]. Each test has its own indication, for example, high level of AST suggests that 
Table 1. Continued 2

\begin{tabular}{|c|c|c|c|c|}
\hline $\begin{array}{c}\text { Scientific } \\
\text { names }\end{array}$ & $\begin{array}{l}\text { Family } \\
\text { names }\end{array}$ & Plant information & Experimental assay & Active compounds \\
\hline $\begin{array}{l}\text { Artemisia } \\
\text { halodendron } \\
\text { Turcz } \\
\text { Artemisia } \\
\text { sphaero- } \\
\text { cephala } \\
\text { Krasch } \\
\text { Artemisia } \\
\text { ordosica } \\
\text { Kraschen }\end{array}$ & Compositae & $\begin{array}{l}\text { A. halodendron Turcz, } A \text {. } \\
\text { sphaerocephala Krasch and } \\
\text { A. ordosica Kraschen are } \\
\text { medicinal herbs, used clinically } \\
\text { to treat several health problems } \\
\text { as intestinal obstruction, rheum } \\
\text { arthritis and parotitis. They are } \\
\text { perennial sub-shrub plants, [17] } \\
\text { characterized by anti-oxidant, } \\
\text { anti-bacterial and cytotoxic } \\
\text { activities }[18,19]\end{array}$ & $\begin{array}{l}\text { These three species oil had a } \\
\text { hepatoprotective activity against } \mathrm{CCl}_{4} \\
\text { induced liver toxicity in mice. Artemisia } \\
\text { sphaerocephala Krasch had a potent } \\
\text { protective effect compared with the two } \\
\text { other plant oils followed by Artemisia } \\
\text { ordosica Kraschen oil and then Artemisia } \\
\text { halodendron Turcz oil. GC/MS examination } \\
\text { of the three plants, indicate the presence } \\
\text { of Bisabolol oxide B, (+)-Trans-Nerolidol } \\
\text { and } \alpha \text {-Bisabolol in all these plants. } \\
\text { However, n-Hexadecanoic acid, biphenyl } \\
\text { and 9,12-Octadecadienoic acid were } \\
\text { present only in Artemisia halodendron } \\
\text { Turcz, oil [17]. }\end{array}$ & $\begin{array}{l}\text { Bisabolol oxide } \mathrm{B},(+) \text { - } \\
\text { trans-nerolidol and } \alpha \text { - } \\
\text { bisabolol in all these plants. } \\
\text { However, n-Hexadecanoic } \\
\text { acid, biphenyl and 9,12- } \\
\text { octadecadienoic acid were } \\
\text { present only in Artemisia } \\
\text { halodendron Turcz oil (18). }\end{array}$ \\
\hline $\begin{array}{r}\text { Artemisia } \\
\text { capillaris }\end{array}$ & Asteraceae & $\begin{array}{l}\text { A. capillaris has been used } \\
\text { clinically for a long time to } \\
\text { treat liver diseases such as } \\
\text { hepatitis. It has been used also } \\
\text { for anti-inflammatory, diuretic, } \\
\text { choleretic, anti-apoptotic and } \\
\text { antidiabetic purposes [20]. }\end{array}$ & $\begin{array}{l}\text { The essential oil of } A \text {. capillaris was } \\
\text { evaluated in vivo by their hepatoprotective } \\
\text { activity against } \mathrm{CCl}_{4} \text { induced liver damage } \\
\text { in mice, by using bio-chemical methods. } \\
\text { For this, the animals were divided into five } \\
\text { groups: The control group were gavaged } \\
\text { with sesame oil. Positive control, mice } \\
\text { were gavaged with } 10 \mathrm{mg} / \mathrm{kg} \text { of bifendate } \\
\text { tablets, for the other groups they were } \\
\text { treated with } 50 \mathrm{mg} / \mathrm{kg} \text { and } 100 \mathrm{mg} / \mathrm{kg} \text { of } \\
\text { A. capillaris oils dissolved in sesame oils. } \\
\text { The treatment was done for six days. In the } \\
\text { sixth day, the tested groups were injected } \\
\text { intra-peritoneally with } 0.2 \% \text { of } \mathrm{CCl}{ }_{4} \text { in } \\
\text { sesame oil (10 } \mathrm{mL} / \mathrm{kg}) \text {. The results showed } \\
\text { that the administration of the essential oil } \\
\text { of } A . \text { capillaris at a dose of } 50 \mathrm{mg} / \mathrm{kg} \text { and } \\
100 \mathrm{mg} / \mathrm{kg} \text { had a potent hepatoprotective } \\
\text { effect against } \mathrm{CCl} 4 \text { in vivo. Indeed, GC-MS } \\
\text { analysis indicated that the oil contains } \\
16.2 \% \text { of citronellol, } 13.9 \% \text { of } 1,8 \text {-cineole, } \\
12.59 \% \text { of camphor, } 11.33 \% \text { of linalol, } \\
7.21 \% \text { of } \alpha \text { pinene, } 3.99 \% \text { of } \beta \text { pinene, } \\
3.22 \% \text { of thymol and } 2.02 \% \text { of myrcene } \\
{[21] \text {. }}\end{array}$ & $\begin{array}{l}\text { Citronellol, 1,8- cineole, } \\
\text { camphor, linalol, } \alpha \text {-pinene, } \\
\beta \text {-pinene, thymol and } \\
\text { myrcene (23). }\end{array}$ \\
\hline
\end{tabular}

there is a loss of functional integrity in the liver, similar to the actions observed in muscle injury, cardiac infraction and viral hepatitis. ALT is a liver enzyme, that catalyzes the conversion of alanine to pyruvate and glutamate, it can detect liver damage [6].

In fact, there are four kinds of liver injury:

- Hepatocellular type, marked by an elevation of serum transaminase [5].
- Cholestatic and infiltrative types, characterized by an elevation in ALP with normal or mild decreasing in serum transaminases. Also, the cholestatic diseases were marked by an increasing of bilirubin levels [5].

The autoimmune liver injury is considered as a problem in the immune system when it attacks liver cells. The etiology of this disease remnant obscure. However, the most categories of 
Table 1. Continued 3

\begin{tabular}{|c|c|c|c|c|}
\hline $\begin{array}{c}\text { Scientific } \\
\text { names }\end{array}$ & $\begin{array}{l}\text { Family } \\
\text { names }\end{array}$ & Plant information & Experimental assay & Active compounds \\
\hline $\begin{array}{c}\text { Athamanta } \\
\text { turbith }\end{array}$ & Umbelliferae & $\begin{array}{l}\text { A. turbith is present in } \\
\text { southeastern Europe; it is } \\
\text { characterized by three sub- } \\
\text { species: } A \text {. turbith ssp. turbith, } \\
\text { A. turbith ssp. hungarica }\left(\mathrm{A}_{\text {thu }}\right) \\
\text { and } A \text {. turbith ssp. Haynaldii } \\
\left(\mathrm{A}_{\text {tha }}\right) \text {. In fact, } \mathrm{A}_{\text {thu }} \text { and } \mathrm{A}_{\text {tha }} \text { have } \\
\text { been taking an importance } \\
\text { in pharmacological studies } \\
\text { particularly that was done } \\
\text { by Tomié Ana and al in } 2010 \\
\text { that have been focused on } \\
\text { evaluation of the protective } \\
\text { effect of the essential oils } \\
\text { of those plants against } \mathrm{CCl}_{4} \\
\text { inducing liver damage in } \mathrm{Swiss} \\
\text { Albino mice. }\end{array}$ & $\begin{array}{l}\text { The oils were prepared by hydrodistillation } \\
\text { from the dried powder of the mature } \\
\text { fruit of the plants, and they were used } \\
\text { as waster emulsions by Tween- } 80 \text {. } \\
\text { Besides, } \mathrm{CCl}_{4} \text { was blended with olive oil. } \\
\text { Actually, in this experiment ten groups are } \\
\text { implemented: Three groups ( } \mathrm{H} 1, \mathrm{H} 2 \text { and } \\
\mathrm{H} 3 \text { ) were administrated respectively by } \\
70,140 \text { and } 280 \mu \mathrm{L} / \mathrm{kg} \text { of } \mathrm{A}_{\text {thu }} \text { oil. Then, } \\
\mathrm{L} 1, \mathrm{~L} 2 \text { and } \mathrm{L} 3 \text { groups have received } \mathrm{A}_{\text {tha }} \\
\text { oil at the same doses of the first essential } \\
\text { oil. One group was administrated only by } \\
\text { CCl }{ }_{4} \text { and two groups received only } 140 \\
\mu \mathrm{L} / \mathrm{kg} \text { of one of the two essential oils. The } \\
\text { last group represents the control (group } \\
\text { not treated at all). Peroxidase (Px), CAT, } \\
\text { glutathione peroxidase, xanthine oxidase } \\
\text { (XOD) parameters were estimated in liver } \\
\text { homogenate spectrophotometrically. } \\
\text { While, AST, ALT, were measured in } \\
\text { serum by commercial kits. The results } \\
\text { of this experiment indicated that the } \\
\text { administration of } 140 \mu \mathrm{g} / \mathrm{kg} \text { of the both } \\
\text { oils, increased CAT activity. Indeed, the all } \\
\text { tested doses showed a decreasing in Px } \\
\text { activity. Furthermore, } 70 \mu \mathrm{L} / \mathrm{kg} \text { of } \mathrm{A}_{\text {thu }} \text { and } \\
140 \mu \mathrm{L} / \mathrm{kg} \text { of } \mathrm{A}_{\text {tha }} \text { reduced AST activity in } \\
\text { comparison with the control [ } 22 \text { ]. }\end{array}$ & $\begin{array}{l}\text { Germacrene } D \text { terpinolene, } \\
\text { myristicin, } \alpha \text {-pinene, } \\
\text { camphene, } \beta \text {-pinene, } \\
\text { myrcene, terpinolene and } \\
\text { p-cymene (25). }\end{array}$ \\
\hline
\end{tabular}

this kind are autoimmune hepatitis, primary biliary cirrhosis and primary sclerosing cholangitis [69].

Hepatotoxines are able to produce oxidative stress by the formation of the LPO, inducing the depletion of ATP and the transition of mitochondrial membrane permeability which lead to the cell apoptosis, rupture and permeabilization of the mem- brane $[70,71]$. Actually, the take at overdoses of the hepatotoxines increase the level of reactive oxygen species and induce the inhibition of antioxidant enzymes like SOD, GPx, GST, GSH and CAT; contribute to the initiation and the progression of liver injury [5].

This review includes the essential oils obtained from 27 
Table 1. Continued 4

\begin{tabular}{|c|c|c|c|c|}
\hline $\begin{array}{c}\text { Scientific } \\
\text { names }\end{array}$ & $\begin{array}{l}\text { Family } \\
\text { names }\end{array}$ & Plant information & Experimental assay & Active compounds \\
\hline Carum carvi $L$ & Apiaceae & $\begin{array}{l}\text { C. carvi } L \text { is a medicinal herb } \\
\text { commonly used as spices, food } \\
\text { industries, pharmacy and in } \\
\text { traditional medicine to treat } \\
\text { flatulence, loss of appetite and } \\
\text { gastrointestinal disorders. It has } \\
\text { antispasmodic and antimicrobial } \\
\text { effects [24]. }\end{array}$ & $\begin{array}{l}\text { C. carvi fruits used to prepare essential } \\
\text { oils by hydro-distillation using n-hexane. } \\
\text { To investigate the hepatoprotective } \\
\text { activity of this oil against } \mathrm{CCl}_{4} \text { in mice in } \\
\text { vivo three groups ( } \mathrm{n}=6 \text { ) were treated } \\
\text { orally with an appropriate solution. Each } \\
\text { group was divided into two subgroups: } \\
\text { Control group: Received saline solution. } \\
\text { Group } 2 \text { a received } \mathrm{CCl}_{4} \text { the group } 2 \mathrm{~b} \\
\text { received } \mathrm{CCl}_{4}+\mathrm{C} \text {. carvi oil. Group 3a } \\
\text { received only the oil of C. carvi (The other } \\
\text { subgroups were used to evaluate the } \\
\text { effect of Coriandrum sativum). Then, LPx, } \\
\text { GSH, GSH/Px, Px, CAT, XOD, AST and ALT } \\
\text { parameters were estimated in serum. } \\
\text { The experiment results indicate that the } \\
\text { treatment with C. carvi oil didn't induce } \\
\text { in liver the pro-oxidative effect. Indeed, } \\
\text { it's able to decrease XOD, GSH and CAT } \\
\text { and increase GSH/Px, Px, and AST. The } \\
\text { results concerning the oil analysis showed } \\
\text { that the main compounds of C. carvi oil } \\
\text { were carvone (78.8\%), limonene (10.1\%), } \\
\text { cis-limonene oxide (1.8\%), trans-carveol } \\
\text { (1.3\%) and menthone (1.2\%) [25]. }\end{array}$ & $\begin{array}{l}\text { Carvone, limonene, cis- } \\
\text { limonene oxide, trans- } \\
\text { carveol and menthone (28). }\end{array}$ \\
\hline $\begin{array}{l}\text { Cinnamomum } \\
\text { osmoph- } \\
\text { loeum }\end{array}$ & Lauraceae & $\begin{array}{l}\text { Taiwan is the origin of } C \text {. } \\
\text { osmophloeum tree. It's } \\
\text { characterized by an altitude } \\
\text { between } 400 \text { and } 1500 \mathrm{~m} \\
\text { [26]. It is used traditionally } \\
\text { as a medicinal plant to treat } \\
\text { inflammation, diabetes, and } \\
\text { enteric infection [26]. Moreover, } \\
\text { trans-cinnamaldehyde, } \\
\text { (-)-aromadendrene, T-cadinol, } \\
\text { and R-cadinol are the major } \\
\text { bioactive compounds of } C \text {. } \\
\text { osmophloeum essential oils. }\end{array}$ & $\begin{array}{l}\text { Research was done on these constituents } \\
\text { to evaluate their hepatoprotective } \\
\text { effect against lipopolysaccharide/ } \\
\text { D-Galactosamine induced acute liver } \\
\text { injury in Mice in vivo compared with } \\
\text { silymarin (Hepatoprotective agent). } \\
\text { In this experiment, the animals were } \\
\text { treated with } 500 \text { ng of LPS and } 25 \text { mg of } \\
\text { D-Galactosamine and } 250 \mu \text { L of saline } \\
\text { before the administration intraperitoneally } \\
\text { of } 100 \mu \text { mol/kg of trans-cinnamaldehyde, } \\
100 \mu \text { mol/kg of (-)-aromadendrene, } 100 \\
\mu \text { mol/kg of T-cadinol and } 100 \mu \text { mol/kg of } \\
\text { R-cadinol. Then, AST, ALT, TNF } \alpha \text { and IL-6 } \\
\text { levels were measured from the serum. The } \\
\text { results revealed that the treatment with } \\
100 \mu \text { mol/kg of the bioactive compounds } \\
\text { of the oil decreased significantly in } \\
\text { serum: AST, ALT, (TNF } \alpha \text { ), and IL- } 6 \text { levels } \\
\text { and they reduced the incidence of liver } \\
\text { damage induced by lipopolysaccharide/ } \\
\text { D-Galactosamine [27]. }\end{array}$ & $\begin{array}{l}\text { Trans-cinnamaldehyde, } \\
\text { (-)-aromadendrene, } \\
\text { T-cadinol, and R-cadinol } \\
\text { (30). }\end{array}$ \\
\hline
\end{tabular}


Table 1. Continued 5

\begin{tabular}{|c|c|c|c|c|}
\hline $\begin{array}{c}\text { Scientific } \\
\text { names }\end{array}$ & $\begin{array}{l}\text { Family } \\
\text { names }\end{array}$ & Plant information & Experimental assay & Active compounds \\
\hline $\begin{array}{c}\text { Coriandrum } \\
\text { sativum L }\end{array}$ & Apiaceae & $\begin{array}{l}\text { C. sativum } L \text { is a medicinal herb } \\
\text { commonly used as spices, } \\
\text { food industries, pharmacy and } \\
\text { traditional medicine to treat } \\
\text { flatulence, loss of appetite and } \\
\text { gastrointestinal disorders. It has } \\
\text { antispasmodic and antimicrobial } \\
\text { effects. }\end{array}$ & $\begin{array}{l}\text { C. sativum fruits used to prepare essential } \\
\text { oils by hydro-distillation using n-hexane. } \\
\text { To investigate the hepatoprotective activity } \\
\text { in vivo of this oil against } \mathrm{CCl}_{4} \text { in mice } \\
\text { three groups ( } \mathrm{n}=6 \text { ) were treated orally } \\
\text { with an appropriate solution. Each group } \\
\text { was divided into two subgroups: Control } \\
\text { group: Received saline solution. Group } 2 a \\
\text { received } \mathrm{CCl}_{4} \text {. Group } 3 \mathrm{~b} \text { received } \mathrm{CCl}_{4}+C \text {. } \\
\text { sativum oil. Group 3a received only the oil } \\
\text { of } C \text {. sativum (The other subgroups were } \\
\text { used to evaluate the effect of } C \text {. carvi). } \\
\text { Then, LPx, GSH, GSH/Px, Px, CAT, XOD, } \\
\text { AST and ALT parameters were estimated } \\
\text { in serum. The results of the experiment } \\
\text { indicate that the treatment with C. sativum } \\
\text { oil increased LPx and Px, GSH, ALT and } \\
\text { AST levels. Oil analysis results showed that } \\
\text { C. sativum oil contains } 74.6 \% \text { of linalol, } \\
5.9 \% \text { of camphor, } 4.6 \% \text { of geranyl acetate, } \\
4 \% \text { of p-cymene, } 2.8 \% \text { of trans-geraniol, } \\
1.2 \% \text { of } \gamma \text {-terpinene and borneol [25]. }\end{array}$ & $\begin{array}{l}\text { Linalol, camphor, geranyl } \\
\text { acetate, p-cymene, } 2 \text { trans- } \\
\text { geraniol, } \gamma \text {-terpinene and } \\
\text { borneol (28). }\end{array}$ \\
\hline $\begin{array}{l}\text { Croton } \\
\text { zehntneri }\end{array}$ & Euphorbiaceae & $\begin{array}{l}\text { C. zehntneri is an aromatic } \\
\text { herb, natives in Northeastern } \\
\text { Brazil. Used traditionally as } \\
\text { appetizing, sedative and to treat } \\
\text { gastrointestinal disorders. }\end{array}$ & $\begin{array}{l}\text { Essential oil of this plant extracted from } \\
\text { the leaves part, showed a significant } \\
\text { hepatoprotective activity. So, to estimate } \\
\text { this effect a research based on the use } \\
\text { of rat model induced liver toxicity by } \\
\text { acetaminophen was carried out. Indeed, } \\
\text { rats were pretreated with different doses } \\
\text { of the oil: } 30,100 \text { and } 300 \mathrm{mg} / \mathrm{kg} \text {, and } \\
750 \mathrm{mg} / \mathrm{kg} \mathrm{N} \text {, acetylcisteine for three } \\
\text { times: } 2,24 \text { and } 48 \text { hours followed by the } \\
\text { injection of } 500 \text { mg/kg acetaminophen. } \\
\text { GOT and GPT levels were measured from } \\
\text { serum to evaluate this protective activity. } \\
\text { GC/MS analysis of the oil indicates the } \\
\text { presence of anethole (57.91\%), estragole } \\
\text { (27.94\%), bicyclogermacrene (5.16\%), } \\
\beta \text {-caryophyllene (1.73\%), myrcene (1.19\%), } \\
\text { germacrene D (1,17\%), 1,8- cineole } \\
\text { (0.77\%), spathulene (0.62\%), } \beta \text {-elemene } \\
\text { (0.36\%), globulol (0.30\%), (E)- } \beta \text {-ocimene } \\
\text { (0.27\%), alloaromadendrene (0.24\%) and } \\
\alpha \text {-phellandrene (0.23\%). Furthermore, C. } \\
\text { zehntneri oils were able to protect liver } \\
\text { damage induced by acetaminophen. It can } \\
\text { reduce GPT and GOT as compared with } \\
\text { acetaminophen group [28]. }\end{array}$ & $\begin{array}{l}\text { Anethole, estragole, } \\
\text { bicyclogermacrene, } \\
\beta \text {-caryophyllene, myrcene, } \\
\text { germacrene D, 1,8- cineole, } \\
\text { spathulene, } \beta \text {-elemene, } \\
\text { globulol, (E)- } \beta \text {-ocimene, } \\
\text { alloaromadendrene and } \\
\alpha \text {-phellandrene (31). }\end{array}$ \\
\hline
\end{tabular}


Table 1. Continued 6

\begin{tabular}{|c|c|c|c|c|}
\hline $\begin{array}{l}\text { Scientific } \\
\text { names }\end{array}$ & $\begin{array}{l}\text { Family } \\
\text { names }\end{array}$ & Plant information & Experimental assay & Active compounds \\
\hline $\begin{array}{c}\text { Cymbopogon } \\
\text { citratus }\end{array}$ & $\begin{array}{l}\text { Poaceae/ } \\
\text { Gramineae }\end{array}$ & $\begin{array}{l}\text { C. citratus is an aromatic } \\
\text { plant, present in tropical and } \\
\text { subtropical countries. Its } \\
\text { essential oil was obtained from } \\
\text { the leaves part [29]. } \\
\text { C. citratus oil has anti-oxidant, } \\
\text { anti-inflammatory, anti-malarial, } \\
\text { analgesic and anti-convulsive } \\
\text { effects [30, 31]. }\end{array}$ & $\begin{array}{l}\text { The hepatoprotective effect of this oil } \\
\text { was examined by using acetaminophen } \\
\text { induced liver damage in mice. Animals } \\
\text { were pre-treated with three doses: } \\
125,250 \text { and } 500 \mathrm{mg} / \mathrm{kg} \text { of the oil } \\
\text { respectively and } 200 \mathrm{mg} / \mathrm{kg} \text { of silymarin } \\
\text { (Standard drug) for seven days, followed } \\
\text { by the injection of } 250 \mathrm{mg} / \mathrm{kg} \text { of the } \\
\text { acetaminophen. ALT, AST, ALP and } \gamma \text { - } \\
\text { glutamyl transferase markers were } \\
\text { estimated from the serum to investigate } \\
\text { the hepatoprotective effect of the oil. GC/ } \\
\text { MS and NMR spectroscopy was used to } \\
\text { analyze the essential oil of } C \text {. citratus. } \\
\text { The results obtained showed that the } \\
\text { oil decreased AST, ALT and ALP levels } \\
\text { as compared with the acetaminophen } \\
\text { group which mean that C. citratus oil } \\
\text { had a hepatoprotective activity against } \\
\text { acetaminophen. Concerning the bioactive } \\
\text { compounds present in the oil there are } \\
24.98 \% \text { of neral as cis-citral and citral B, } \\
27.3 \% \text { of geranial as trans-citral and citral } \\
\text { A and } 30.75 \% \text { myrcene [29]. }\end{array}$ & $\begin{array}{l}\text { Neral as cis-citral and citral B. } \\
\text { Geranial as trans-citral and } \\
\text { citral A and myrcene (32). }\end{array}$ \\
\hline $\begin{array}{c}\text { Foeniculum } \\
\text { vulgare }\end{array}$ & Umbelliferae & $\begin{array}{l}\text { F. vulgare is an annual aromatic } \\
\text { plant. The leaves, seeds and } \\
\text { stems parts of this herb are } \\
\text { comestible. In fact, dried fruits } \\
\text { of the plant are commonly } \\
\text { used in medicinal preparations } \\
\text { to treat flatulence, bloating, } \\
\text { spasmodic, gastrointestinal, } \\
\text { pediatric colic and respiratory } \\
\text { problems. It increases libido } \\
\text { and relieved the menopause } \\
\text { symptoms [32]. Moreover, it is } \\
\text { used in cosmetic. }\end{array}$ & $\begin{array}{l}\text { Several works have been done on } F \text {. vulgare } \\
\text { oil in order to evaluate their protective } \\
\text { activity against } \mathrm{CCl}_{4} \text { induced acute liver } \\
\text { toxicity in rats showed that the plant oils } \\
\text { have hepatoprotective action particularly } \\
\text { that was done by Hanefi Özbek and al in } \\
2003 \text { and in } 2004 \text { [33, 34]. In fact, the } \\
\text { experiment was focused on the use of } \\
\text { three groups ( } \mathrm{n}=8 \text { ) of rats: Control group: } \\
\text { Animals were injected intraperitoneally } \\
\text { with } 0.2 \text { mL of isotonic saline solution. } \\
\text { Group } 2 \text { : Rats have received } 1,5 \text { mL/kg of } \\
\text { CCl }{ }_{4} \text { diluted in olive oil. Group } 3: \text { Rats have } \\
\text { received } 1.5 \mathrm{~mL} / \mathrm{kg}+0.3 \text { mL/kg of the } F \text {. } \\
\text { vulgare oil, which was prepared from the } \\
\text { seeds powder by steam distillation. AST, } \\
\text { ALT, ALP and bilirubin marker enzymes } \\
\text { were measured from the serum during } \\
\text { seven weeks for three times a week. The } \\
\text { results indicated that } F \text {. vulgare essential } \\
\text { oil has a potent protective activity against } \\
\text { CCl }{ }_{4} \text {. GC analysis of this oil showed the } \\
\text { presence of } 74.8 \% \text { of (E)-anethole, } 11.1 \% \\
\text { of limonene, } 4.7 \% \text { of methyl chavicol, } 2.5 \% \\
\text { of fenchone, } 1.3 \% \text { of } \alpha \text { pinene and } 1.2 \% \text { of } \\
\text { (Z) - } \beta \text {-ocimene [33]. }\end{array}$ & $\begin{array}{l}\text { (E)- anethole, limonene, } \\
\text { methyl chavicol, fenchone, } \alpha \\
\text { pinene and } 1 \text { (Z) - } \beta \text {-ocimene } \\
\text { (36). }\end{array}$ \\
\hline
\end{tabular}


Table 1. Continued 7

\begin{tabular}{|c|c|c|c|c|}
\hline $\begin{array}{c}\text { Scientific } \\
\text { names }\end{array}$ & $\begin{array}{l}\text { Family } \\
\text { names }\end{array}$ & Plant information & Experimental assay & Active compounds \\
\hline $\begin{array}{c}\text { Hypericum } \\
\text { scabrum }\end{array}$ & Hypericaceae & $\begin{array}{l}\text { H. scabrum is a medicinal plant, } \\
\text { which has a several therapeutic } \\
\text { actions as anti-depressant, } \\
\text { bronchodilator, management } \\
\text { of cardiovascular disorder, } \\
\text { antispasmodic, wound healing } \\
\text { and antibacterial activities [35- } \\
\text { 37]. }\end{array}$ & $\begin{array}{l}\text { The essential oils of } \mathrm{H} \text {. scabrum have been } \\
\text { estimated for their hepatoprotectice } \\
\text { effect on acetaminophen induced liver } \\
\text { stress in rats. Animals were pre-treated } \\
\text { with two doses: } 100 \text { and } 200 \mathrm{mg} / \mathrm{kg} \\
\text { of the oil respectively, diluted in } 400 \\
\mathrm{~mL} \text { of DMSO (Diméthylsulfoxyde), and } \\
10 \mathrm{mg} / \mathrm{kg} \text { of butylated hydroxytoluene } \\
\text { (Positive control), followed immediately } \\
\text { by the injection of } 500 \mathrm{mg} / \mathrm{kg} \text { of the } \\
\text { acetaminophen dissolved in } 400 \mathrm{~mL} \\
\text { of DMSO. SOD, CAT, GSH, LPO, FRAP } \\
\text { markers have been estimated from the } \\
\text { serum after } 2,4,16 \text { and } 24 \text { hours of the } \\
\text { treatments. The results showed that LPO, } \\
\text { FRAP and SOD levels were lowered in the } \\
\text { group treated with the oil as compared } \\
\text { with acetaminophen group. Then, the liver } \\
\text { biopsies have confirmed the protective } \\
\text { effect of the oils [38]. }\end{array}$ & $\begin{array}{l}\alpha \text {-thujan, } \alpha \text { - pinene, } \\
\alpha \text { - Fenchene, camphene, } \\
\beta \text {-pinene, } \beta \text { - myrcene, } \\
\alpha \text {-phellandrene, } \alpha \text { - } \\
\text { terpinene, } p \text { - cymene, } \\
\text { limonene, (Z) } \beta \text { - ocimene, } \\
\text { (E) } \beta \text { - ocimene, } \gamma \text { - terpinene, } \\
\text { terpinolene, borneol, } \\
\text { terpin } 4 \text { ol, pulegone, } \\
\text { thymol, carvacrol, } \alpha \text { - } \\
\text { cubebene, } \alpha \text { - copaene, } \beta \text { - } \\
\text { elemene, } \beta \text { - caryophyllene, } \\
\alpha \text {-humulene, germacrene-D, } \\
\text { bicyclogermacrene, } \\
\Delta \text { cadinene, } 1,4 \text { - } \\
\text { cadinadiene, caryophyllene } \\
\text { oxide and epi- } \alpha \text { - cadinol (42). }\end{array}$ \\
\hline Hyptis crenata & Lamiaceae & $\begin{array}{l}\text { H. crenata leaves used } \\
\text { traditionally to cure } \\
\text { gastrointestinal and liver } \\
\text { disorders [39]. Essential oil } \\
\text { of this plant, obtained from } \\
\text { aerial parts, contains } 32.78 \% \\
\text { of camphor, } 18.02 \% \text { of } \\
\text { 1.8-cineole, } 13.37 \% \text { of } \alpha \text {-pinene } \\
\text { and } 12.86 \% \text { of } \beta \text {-caryophyllene } \\
\text { [40]. }\end{array}$ & $\begin{array}{l}\text { To estimate the hepatoprotective effect of } \\
\text { this oil a research focused on the use of } \\
\text { rat model produced liver dysfunctions by } \\
\text { cecal ligation and puncture (CLP). Animals } \\
\text { were divided into four groups treated with } \\
\text { an appropriate solution every } 12 \text { hours } \\
\text { for } 24 \text { hours: Sham, sham + } 300 \mathrm{mg} / \mathrm{kg} \\
\text { of } \mathrm{H} \text {. crenata oils, CLP + } 300 \mathrm{mg} / \mathrm{kg} \text { of } \mathrm{H} \text {. } \\
\text { crenata oils and CLP groups. ALT, ALP, CAT, } \\
\text { SOD, glutathione peroxidase (GPx), LPO } \\
\text { and malondialdehyde parameters were } \\
\text { measured in hepatic tissue to investigate } \\
\text { the oxidative stress in the liver. Then, the } \\
\text { histological examination was carried out to } \\
\text { confirm the results. The treatment with } \mathrm{H} \text {. } \\
\text { crenata oils have normalized the level of } \\
\text { ALT, ALP and bilirubin and it inhibited the } \\
\text { increasing of GPx and LPO, which mean } \\
\text { that the plant oils had a hepatoprotective } \\
\text { action on sepsis, induced liver injury [41]. }\end{array}$ & $\begin{array}{l}\text { Camphor, 1.8-cineole, } \\
\alpha \text {-pinene and } \\
\beta \text {-caryophyllene (45). }\end{array}$ \\
\hline
\end{tabular}

plants belonging to 12 families as the table show: Lamiaceae (7 species), Asteraceae (6 species), Umbellifereae (3 species), Apiaceae (3 species), Rutaceae, Anacardiaceae, Bignoniaceae, Euphorbiaceae, Hypericaceae, Lauraceae, Poaceae and Zingiberaceae. These essential oils were shown that have an antioxidant activity which mean that contain the bioactive compounds able to neutralize free radicals and then decrease the oxidative stress in the liver.

According to this work, the major compounds isolated from some of these essential oils were cited. The most of those compounds belong to terpene class as Cineol, Carvacrol and thymol.

Cineol or Eucalyptol is also known as cajeputol, is a terpene oxide that found in some plant essential oil [73] particularly 
Table 1. Continued 8

\begin{tabular}{|c|c|c|c|c|}
\hline $\begin{array}{c}\text { Scientific } \\
\text { names }\end{array}$ & $\begin{array}{l}\text { Family } \\
\text { names }\end{array}$ & Plant information & Experimental assay & Active compounds \\
\hline $\begin{array}{c}\text { Marrubium } \\
\text { vulgare } L\end{array}$ & Lamiaceae & $\begin{array}{l}\text { M. vulgare natives in Europe, } \\
\text { Asia and in the Mediterranean } \\
\text { area. It is used traditionally as } \\
\text { expectorant, antispasmodic and } \\
\text { in general respiratory infections. } \\
\text { Furthermore, this plant is used } \\
\text { also externally, in ulcers and } \\
\text { wounds [24]. }\end{array}$ & $\begin{array}{l}\text { The essential oils of } M \text {. vulgare } L \text { obtained by } \\
\text { hydro-distillation of the aerial parts of the } \\
\text { herb, were tested for the hepatoprotective } \\
\text { effects at a dose of } 50 \mathrm{mg} / \mathrm{kg} \text { body weight. } \\
\text { For that, the oil was administered every } \\
\text { day for } 15 \text { days before the injection of } \\
5 \mathrm{~mL} / \mathrm{kg} \text { of } \mathrm{CCl}_{4} \text { "intraperitoneally". The } \\
\text { chemical composition of } M \text {. vulgare oils } \\
\text { was defined by "GC-MS" analysis. The } \\
\text { results showed that the } M \text {. vulgare oil had } \\
\text { a potent hepatoprotective effect which may } \\
\text { be explicated by their powerful antioxidant } \\
\text { activity. Indeed, this oil contains } 36 \\
\text { components: } 99.79 \% \text { of the total oil } \\
\text { profile, } 20.11 \% \text { of thymol and } 15.66 \% \text { of } \\
\text { E, } \beta \text {-Farnesene which represent the main } \\
\text { constituents [14]. }\end{array}$ & $\begin{array}{l}\beta \text { - Pinene, methyl chavicol, } \\
\text { E- anethol, thymol, Carvacrol } \\
\text { (15). }\end{array}$ \\
\hline $\begin{array}{l}\text { Oroxylum } \\
\text { indicum L. }\end{array}$ & Bignoniaceae & $\begin{array}{l}\text { O. indicum L. is a tree that growth } \\
\text { in India, China, Malaysia, } \\
\text { Thailand, Cochin, Ceylon, } \\
\text { Indonesia, and Philippines } \\
\text { [42]. In herbal medicine, } \\
\text { O. indicum L. used to treat } \\
\text { bronchitis, inflammation, } \\
\text { respiratory diseases such as } \\
\text { asthma, leucoderma, intestinal } \\
\text { worms, fever, diarrhea and anal } \\
\text { disorders [43]. Phytochemically, } \\
\text { O. indicum L contains flavonoids } \\
\text { as apigenin, baicalein, chrysin, } \\
\text { oroxylin A, scutellarin and tetuin } \\
\text { and it contains also cyclo-hexyl- } \\
\text { ethanoids, pterocarpanoids, } \\
\text { sterols and volatile oil [44]. }\end{array}$ & $\begin{array}{l}\text { The essential oil of this plant leaves showed } \\
\text { a hepatoprotective effect against } \mathrm{CCl}_{4} \\
\text { produced liver toxicity in rats. So, to } \\
\text { evaluate this activity, serum ALT, ALP } \\
\text { and AST were estimated of the tested } \\
\text { animals. Actually, once dose of the oil } \\
\text { was tested daily for seven days (10 mg/ } \\
\mathrm{mL} \text { ). The positive control was pre-treated } \\
\text { with } 25 \mathrm{mg} / \mathrm{mL} \text { of the standard drug: } \\
\text { Silymarin, followed by the injection of } \\
\mathrm{CCl}_{4} \text {. GC/MS examination of the essential } \\
\text { oils showed the presence of } 63.81 \% \text { of } \\
\text { oxygenated constituents as sesquiterpene } \\
\text { ketones, esters, diterpene ketones, } \\
\text { ketones, sesquiterpene alcohol, alcohols } \\
\text { and sesquiterpene esters and } 26.04 \% \\
\text { of non-oxygenated compounds like } \\
\text { sesquiterpenes and aliphatic hydrocarbon } \\
\text { [42]. }\end{array}$ & $\begin{array}{l}\text { Flavonoids as apigenin, } \\
\text { baicalein, chrysin, oroxylin } \\
\text { A, scutellarin and tetuin. } \\
\text { Cyclo-hexyl-ethanoids, } \\
\text { pterocarpanoids, sterols and } \\
\text { volatile oil (49). }\end{array}$ \\
\hline
\end{tabular}

Achillea biebersteinii Afan, Artemisia capillaris, Croton zehntneri, Hyptis crenata and Rosmarinus officinalis essential oils. It is frequently used as an aromatic agent for food products and it is used by the pharmaceutical industry in the production of the drugs. Cineol has been used as a growth inhibitor and to treat the symptoms of respiratory tract diseases [72]. Indeed, there are several studies have shown that this compound has an anti-inflammatory and analgesic effects [73]. In addition, it has shown an inhibitory activity in vivo and in vitro on the production of inflammatory mediators such as cytokines, leukotrienes and prostaglandins from human blood monocytes stimulated by lipopolysaccharides [74].

Carvacrol or 2-methyl-5-(1-methylethyl)-phenol is monoterpenic phenol occurs in some essential oil plants belonging particularly of the family Lamiaceae (Ajuga iva, Thymus vulgaris), Asteraceae (Achillea biebersteinii Afan) and Apiaceae (Anethum graveolens). It is used in sweets, beverages, and chewing gum as a flavoring agent [75]. This bioactive compound has several pharmacological activities including antioxidant [76], anti-inflammatory [77], antimicrobial [78], antibacterial, anti- 
Table 1. Continued 9

\begin{tabular}{|c|c|c|c|c|}
\hline $\begin{array}{c}\text { Scientific } \\
\text { names }\end{array}$ & $\begin{array}{l}\text { Family } \\
\text { names }\end{array}$ & Plant information & Experimental assay & Active compounds \\
\hline $\begin{array}{l}\text { Pimpinella } \\
\text { anisum }\end{array}$ & Umbelliferae & $\begin{array}{l}\text { P. anisum is a medicinal plant, } \\
\text { distributed in Iran, Egypt, } \\
\text { Greece and Turkey [44]. It } \\
\text { is used traditionally as anti- } \\
\text { inflammatory, analgesic } \\
\text { and anticonvulsant agents } \\
{[45,46] \text {. In some works, the }} \\
\text { pharmacological properties of } \\
\text { P. anisum oils obtained from } \\
\text { its seeds have been evaluated. } \\
\text { It has been found that it has } \\
\text { several biological activities as } \\
\text { antioxidant effect [47]. }\end{array}$ & $\begin{array}{l}\text { It was reported that diethyl ether extract of } \\
\text { P. anisum seeds improved } \mathrm{CCl}_{4} \text { induced } \\
\text { liver damage. Moreover, the essential oil of } \\
\text { this plant can protect rats from aspartame } \\
\text { produced liver injury. So, to be sure of this } \\
\text { hypothesis, Akram Jamshidzadeh and al in } \\
2015 \text { have investigated the effect of this } \\
\text { oil against } \mathrm{CCl}_{4} \text {. Rats were pre-treated with } \\
\text { two different doses of the } P \text {. anisum oil: } \\
20 \mathrm{mg} / \mathrm{kg} \text { and } 100 \mathrm{mg} / \mathrm{kg} \text {, respectively, } \\
\text { and } 1.5 \mathrm{~mL} / \mathrm{kg} \text { of } \mathrm{CCl}{ }_{4} \text { dissolved in olive } \\
\text { oil. Concerning, the control group was } \\
\text { pretreated with } 1.5 \mathrm{mg} / \mathrm{mL} \text { of the olive } \\
\text { oil. Then, the serum biomarkers were } \\
\text { estimated after } 24 \text { hours of } \mathrm{CCl}_{4} \text { injection } \\
\text { and the histological examination was } \\
\text { performed in order to confirm the obtained } \\
\text { results. The experiment results revealed } \\
\text { that CCl }{ }_{4} \text { increased serum transaminases, } \\
\text { LDH and } \mathrm{LPx} \text {. Thus, the treatement with } \\
\text { the oil at dose of } 20 \mathrm{mg} / \mathrm{kg} \text { of } P \text {. anisum oil } \\
\text { had no significant action on GSH and LPx } \\
\text { depletion. Nevertheless, the medication } \\
\text { with } 100 \mathrm{mg} / \mathrm{kg} \text { of the essential oil was } \\
\text { able to improve the different parameters } \\
\text { that have measured [48]. }\end{array}$ & $\begin{array}{l}\text { Linalool, estragole, cis- } \\
\text { anethole, trans-anethole, } \\
\gamma \text {-himachalene, zingiberene, } \\
\text { anisylacetone, o-isoeugenol } \\
\text { and butanoic acid and } \\
\text { 2-methyl-, 4-methoxy-2-(3- } \\
\text { methyloxiranyl) phenyl ester } \\
\text { (54). }\end{array}$ \\
\hline
\end{tabular}


Table 1. Continued 10

\begin{tabular}{|c|c|c|c|c|}
\hline $\begin{array}{c}\text { Scientific } \\
\text { names }\end{array}$ & $\begin{array}{l}\text { Family } \\
\text { names }\end{array}$ & Plant information & Experimental assay & Active compounds \\
\hline $\begin{array}{c}\text { Rosmarinus } \\
\text { officinalis }\end{array}$ & Lamiaceae & $\begin{array}{l}\text { R. officinalis is a perennial shrub, } \\
\text { evergreen. It possesses a lot } \\
\text { of therapeutic applications } \\
\text { in traditional medicine, it has } \\
\text { been reported that it is able } \\
\text { to treat diabetes, respiratory } \\
\text { diseases, stomach problems } \\
\text { and inflammatory disorders. } \\
\text { Actually, Rosemary species has } \\
\text { been extensively accepted as } \\
\text { one of the most species that } \\
\text { had an anti-oxidant activity [52]. }\end{array}$ & $\begin{array}{l}\text { The water and ethanolic extracts of the plant } \\
\text { have a hepatoprotective activity. So, other } \\
\text { research interests of the essential oils of } \\
\text { this plant were performed to evaluate the } \\
\text { hepatoprotective activity of the aerial parts } \\
\text { of } R \text {. officinalis at a dose of } 50 \mathrm{mg} / \mathrm{kg} \text { body } \\
\text { weight. The oil was got by hydro-distillation. } \\
\text { Moreover, it was administered to animals } \\
\text { every day for } 15 \text { days before the injection } \\
\text { of } \mathrm{CCl}_{4} \text { "intraperitoneally". The chemical } \\
\text { composition of } R \text {. officinalis oils was } \\
\text { defined by GC-MS examination. Therefore, } \\
\text { the results showed that } R \text {. officinalis oil } \\
\text { contains } 19 \text { components: } 99.63 \% \text { of the } \\
\text { total oil profile, } 35.21 \% \text { of } 1,8 \text {-cineol and } \\
24.71 \% \text { verbenone which are the main } \\
\text { constituents of this oil. Furthermore, the } \\
\text { experiment indicated that } R \text {. officinalis } \\
\text { oils possess a significant hepatoprotective } \\
\text { activity [14, } 52 \text { ]. }\end{array}$ & $\begin{array}{l}\alpha \text {-Pinene, camphene, 1,8- } \\
\text { cineole, terpinolene, linalool, } \\
\text { camphor, isoborneol, } \\
\text { borneol, lavandulol, } \\
\text { verbenone, citronellol, } \\
\text { p-mentha-1-en-9-ol and } \\
\text { geranyl formate (15). }\end{array}$ \\
\hline $\begin{array}{l}\text { Satureja } \\
\text { rechingeri }\end{array}$ & Lamiaceae & $\begin{array}{l}\text { S. rechingeri is a medicinal herb } \\
\text { that distributes in Europe, } \\
\text { northern Africa, and Asia Minor } \\
\text { [53]. It is used traditionally in } \\
\text { Iran for curing many diseases } \\
\text { such as nausea, infectious } \\
\text { disorders, muscle pains and } \\
\text { cramps [54]. Many researches } \\
\text { showed that the active } \\
\text { compounds of this plant have } \\
\text { beneficial properties like an } \\
\text { anti-inflammatory, antioxidant, } \\
\text { anti-noceceptive, antiviral, } \\
\text { antifungal, antibacterial, } \\
\text { antidiarrheal, antispasmodic } \\
\text { and vasodilatory effect [53, 55]. }\end{array}$ & $\begin{array}{l}\text { S. Rechingeri essential oils had a } \\
\text { hepatoprotective activity against } \\
\text { acetaminophen induced hepatotoxicity in } \\
\text { rats. In this study, the animals were pre- } \\
\text { treated with one dose of the essential } \\
\text { oil: } 20 \mathrm{mg} / \mathrm{kg} \text { diluted in } 400 \mathrm{~mL} \text { DMSO. } \\
\text { Followed by the administration of } 500 \\
\text { mg/kg acetaminophen dissolved in } \\
400 \mathrm{~mL} \text { DMSO after } 14 \text { days of the } \\
\text { treatment. The results indicated that } \\
\text { acetaminophen decrease the activities } \\
\text { of GPx, glutathione reductase (GR), SOD } \\
\text { and GSH content and increased AST } \\
\text { activity and the level of FRAP and LPO. } \\
\text { While, the treatment with the essential } \\
\text { oil protected effectively the liver against } \\
\text { toxicity induced by the hepatotoxine. It is } \\
\text { increased GSH, SOD, GPx and GR levels. } \\
\text { Then, the histopathological examination } \\
\text { was confirmed this activity, it showed a } \\
\text { decreasing in the number of necrotic cells } \\
\text { and of degenerated lobules [53]. }\end{array}$ & $\begin{array}{l}\alpha \text {-Thujene, } \alpha \text {-pinene, } \\
\text { camphene, } \beta \text {-pinene, } \\
\beta \text {-myrcene, } \alpha \text {-terpinene, } \\
p \text {-cymen, limonene, } \\
\gamma \text {-terpinene, linalool, } \\
\text { borneol, terpinen-4-ol, } \\
\beta \text {-fenchyl acetate (endo), } \\
\text { neral, geraniol, thymol, } \\
\text { Carvacrol, thymol acetate, E- } \\
\text { caryophyllene, caryophyllene } \\
\text { oxide (62). }\end{array}$ \\
\hline
\end{tabular}

viral [79], antitumor [80] and hepatoprotective [75] properties.

Thymol or paramethyl-isopropyl-phenol is the main bioactive compounds of the plant essential oils as Artemisia capillaris, Marrubium vulgare $L$ and Thymus capitatus essential oils. Thymol was shown that had a hepatoprotective activity against
$\mathrm{CCl}_{4}$ induced liver toxicity in mice. In fact, the administration of thymol at a dose $300 \mathrm{mg} / \mathrm{kg}$ in mice, shown an inhibition of LPO that induced by $\mathrm{CCl}_{4}[81]$. 
Table 1. Continued 11

\begin{tabular}{|c|c|c|c|c|}
\hline $\begin{array}{c}\text { Scientific } \\
\text { names }\end{array}$ & $\begin{array}{l}\text { Family } \\
\text { names }\end{array}$ & Plant information & Experimental assay & Active compounds \\
\hline $\begin{array}{l}\text { Thymus } \\
\text { capitatus }\end{array}$ & Labiatae & $\begin{array}{l}\text { T. capitatus is an herbaceous } \\
\text { shrub, perennial used } \\
\text { traditionally to treat several } \\
\text { health problems. It is known } \\
\text { as antitussive, antipyretic, } \\
\text { carminative and disphoretic } \\
\text { [56]. It was exploited for their } \\
\text { reputation as medicinal plants } \\
\text { and for their oils [57]. }\end{array}$ & $\begin{array}{l}\text { The aerial parts of this plant were subjected } \\
\text { to hydrodistillation for obtaining the } \\
\text { essential oils to evaluate it by their } \\
\text { hepatoprotective activity. Fifty } \mathrm{mg} / \mathrm{kg} \\
\text { body weight is the dose of the oil that was } \\
\text { tested to examine this activity. For this } \\
\text { reason, the oil was administered every } \\
\text { day for } 15 \text { days before the injection of } \\
5 \mathrm{~mL} / \mathrm{kg} \text { of } \mathrm{CCl}_{4} \text { "intraperitoneally". The } \\
\text { chemical composition of } T \text {. capitatus oils } \\
\text { was determined by "GC-MS". The results } \\
\text { indicated that the essential oils possess } \\
27 \text { constituents among these components: } \\
99.48 \% \text { of the total oil profile and } 90.15 \% \\
\text { of thymol. Moreover, the experiment } \\
\text { showed that the essential oil of T. capitatus } \\
\text { had a significant hepatoprotective activity } \\
\text { [14]. }\end{array}$ & $\begin{array}{l}\alpha \text { and } \beta \text { - pinene, } \beta \text {-myrcene, } \\
\alpha \text {-phellandrene, } \alpha \text {-terpinene, } \\
\text { p-cymene, 1,8-cineole, } \\
\text { terpineolene, dehydro- } \\
\text { sabina ketone, iso-3- } \\
\text { thujanol, neo-3- thujanol, } \\
\text { camphene hydrate, } \\
\text { isoborneol, neo-3- menthol, } \\
\text { neo-iso- isopulegol, neo- } \\
\text { Dihydro carveol, verbanol, } \\
\text { E- dihydro carvone, Z- } \\
\text { ocimenone, thymol and } \\
\text { carvacrol (15). }\end{array}$ \\
\hline $\begin{array}{l}\text { Thymus } \\
\text { vulgaris }\end{array}$ & Lamiaceae & $\begin{array}{l}\text { The leaves of } T \text {. vulgaris have an } \\
\text { important value in nutrition; } \\
\text { particularly it is used as a spice, } \\
\text { freshly or dried. It was used } \\
\text { also in traditional medicine as } \\
\text { antiseptic, antimicrobial, anti- } \\
\text { inflamatory, carminative and } \\
\text { antioxidative activities [58, 59]. }\end{array}$ & $\begin{array}{l}\text { The fresh leaves of } T \text {. vulgaris were used } \\
\text { to prepare the essential oil. To assess } \\
\text { the hepatoprotective effect of this oil, six } \\
\text { groups of mice ( } n=5 \text { ) were used. Each } \\
\text { group was treated for seven days: Group } \\
1 \text { represents the control. Group 2: the } \\
\text { mice were administrated by T. vulgaris oil } \\
\text { vehicle saline (contains } 0.1 \% \text { of Tween } \\
80 \text { ). Groups } 3,4 \text { and } 5 \text { : were treated with } \\
\text { the oil at different doses: } 125,250 \text { and } \\
500 \text { mg/kg respectively. The last group } \\
\text { received } 200 \text { mg/kg of silymarin (Standard } \\
\text { drug). All animals were fasted for } 8 \text { hours } \\
\text { after the treatment time and then they } \\
\text { were administrated orally by } 250 \text { mg/kg of } \\
\text { the acetaminophen induced liver damage, } \\
\text { exception the control group which was } \\
\text { received saline contained } 0,1 \% \text { of Tween } \\
80 . \text { After } 12 \text { hours, the levels of AST, ALT } \\
\text { and ALP bio-markers were measured. GC/ } \\
\text { MS analysis was carried out to identify } \\
\text { the compounds present in the oil. The } \\
\text { results showed that the treatments with } \\
250 \text { and } 500 \text { mg/kg of } T \text {. vulgaris oil for } \\
\text { seven days reduce ALT, AST and ALP levels } \\
\text { as compared with the control. Moreover, } \\
\text { the essential oil indicated the presence } \\
\text { of } 45.54 \% \text { of carvacrol, } 22.96 \% \text { of } \alpha \\
\text { terpineol and } 14.29 \% \text { of endo-borneol [6]. }\end{array}$ & $\begin{array}{l}\alpha \text {-Pinene, camphene, } \\
\beta \text {-myrcene, carene, } \\
\text { p-cymene, } \gamma \text {-terpinene, } \\
\alpha \text {-terpineol, thymol, caryo- } \\
\text { phyllene, Humulene (67) } \\
\text { carvacrol, } \alpha \text { terpineol and } \\
\text { endo-borneol (6). }\end{array}$ \\
\hline
\end{tabular}


Table 1. Continued 12

\begin{tabular}{|c|c|c|c|c|}
\hline $\begin{array}{c}\text { Scientific } \\
\text { names }\end{array}$ & $\begin{array}{l}\text { Family } \\
\text { names }\end{array}$ & Plant information & Experimental assay & Active compounds \\
\hline $\begin{array}{l}\text { Zingiber } \\
\text { officinale }\end{array}$ & Zingiberaceae & $\begin{array}{l}\text { Z. officinale is a medicinal herb } \\
\text { known by its rhizome which } \\
\text { used as spice. It has several } \\
\text { physiological properties like } \\
\text { decreasing nausea [60], } \\
\text { preventing cardiovascular } \\
\text { disorders [61], inhibiting the } \\
\text { proliferation of cancer cells [62]. } \\
\text { Also, it improves the intestines, } \\
\text { stomach, liver functions [63, 64] } \\
\text { and it is used to treat diabetes } \\
\text { [65] and atherosclerosis [61]. } \\
\text { Z. Officinale essential oils are } \\
\text { commonly used in cosmetics } \\
\text { and in food. Furthermore, it } \\
\text { has been declared that ginger } \\
\text { oil had an antioxidant and } \\
\text { anticancer effect [66, 67]. }\end{array}$ & $\begin{array}{l}\text { The hepatoprotective effect of this oil } \\
\text { was evaluated; using Lieber-DeCarli diet } \\
\text { induced alcoholic fatty liver disease and } \\
\text { high fat diet induced nonalcoholic fatty } \\
\text { liver disorder. The animals were divided } \\
\text { into three groups: Control group in which } \\
\text { the mice were fed with normal liquid diet. } \\
\text { Group } 2 \text { contains animals that they fed } \\
\text { with ethanol containing Lieber-DeCarli } \\
\text { diet. Then, they are treated with } 2.5 \text { or } \\
\text { 12.5 mg/kg of ginger oil or with } 0.375 \\
\text { or } 1.875 \text { mg/kg of citral mixed with olive } \\
\text { oil, for four weeks. The normal group was } \\
\text { received only olive oil. Liver biochemical } \\
\text { parameters and liver enzymes have } \\
\text { been measured. Then, the histological } \\
\text { examination was performed from liver } \\
\text { biopsy to confirm the results obtained } \\
\text { [63]. Regarding the effect of ginger oil } \\
\text { against nonalcoholic fatty liver disease, } \\
\text { the animals were divided into groups ( } \mathrm{n}= \\
8 \text { ) and they received } 12.5,62.5 \text { and } 125 \\
\text { mg/kg of ginger oil respectively, and } 2.5 \\
\text { or } 25 \text { mg/kg of citral after two weeks of } \\
\text { feeding. The medication was done for } 12 \\
\text { weeks. Then, they received olive oil with } \\
\text { the same volume. The results showed } \\
\text { that } Z \text {. Officinale essential oils and citral } \\
\text { had a hepatoprotective effect against } \\
\text { alcoholic fatty liver disease. Besides, the } \\
\text { administration of ginger oil at a dose } 62.5 \\
\text { and } 125 \text { mg/kg and the treatment with } \\
25 \text { mg/kg of citral reduced significantly } \\
\text { hepatic liver accumulation [68]. }\end{array}$ & $\begin{array}{l}\text { Z. Officinale essential oil } \\
\text { contains } \beta \text {-zingiberene, } \\
\text { 1,8-cineole+limonene+ } \beta \text { - } \\
\text { phellandrene, geraniol, } \\
\text { neral, } \beta \text {-bisabolene and } \\
\beta \text {-sesquiphellandrene (77). }\end{array}$ \\
\hline
\end{tabular}

\section{CONCLUSION}

In conclusion, this study classifies 27 plants belonging to 12 families: Lamiaceae (7 species), Asteraceae (6 species), Umbellifereae (3 species), Apiaceae (3 species), Rutaceae, Anacardiaceae, Bignoniaceae, Euphorbiaceae, Hypericaceae, Lauraceae, Poaceae and Zingiberaceae. Those plants allow giving the essential oils which have been studied by their hepatoprotective activity.

The review covers also the major compounds isolated from some of these essential oils. The most of those compounds belong to terpene class; among these active constituents: Cineol,
Carvacrol and thymol. Thus, the different essential oils that have been cited in this review were shown that have an antioxidant activity which play a key role in the reducing of the oxidative stress induced by the hepatotoxines. However, several efforts must be made to value these essential oils and identify the active constituents responsible for the hepatoprotective activity.

\section{ACKNOWLEDGMENT}

This study has been financed by CNRST, Morocco (PPR2). 


\section{CONFLICT OF INTEREST}

The authors declare that there is no conflict of interest.

\section{ORCID}

Nour Elhouda Daoudi, https://orcid.org/0000-0002-3516-318X

Mohamed Bnouham, https://orcid.org/0000-0001-9473-1290

\section{REFERENCES}

1. Bakkali F, Averbeck S, Averbeck D, Idaomar M. Biological effects of essential oils--a review. Food Chem Toxicol. 2008;46(2):44675 .

2. Gaire S, O'Connell M, Holguin FO, Amatya A, Bundy S, Romero A. Insecticidal properties of essential oils and some of their constituents on the Turkestan cockroach (Blattodea: Blattidae). J Econ Entomol. 2017;110(2):584-592.

3. Burt S. Essential oils: their antibacterial properties and potential applications in foods--a review. Int J Food Microbiol. 2004;94(3):223-53.

4. Bouchra C, Achouri M, Idrissi Hassani LM, Hmamouchi M. Chemical composition and antifungal activity of essential oils of seven Moroccan Labiatae against Botrytis cinerea Pers: Fr. J Ethnopharmacol. 2003;89(1):165-9.

5. Musana KA, Yale SH, Abdulkarim AS. Tests of liver injury. Clin Med Res. 2004;2(2):129-31.

6. Grespan R, Aguiar RP, Giubilei FN, Fuso RR, Damião MJ, Silva EL, et al. Hepatoprotective effect of pretreatment with Thymus vulgaris essential oil in experimental model of acetaminopheninduced injury. Evid Based Complement Alternat Med. 2014; 2014:954136.

7. Al-Said MS, Mothana RA, Al-Yahya MM, Rafatullah S, AlSohaibani MO, Khaled JM, et al. GC-MS analysis: in vivo hepatoprotective and antioxidant activities of the essential oil of achillea biebersteinii afan. Growing in Saudi Arabia. Evid Based Complement Alternat Med. 2016;2016:1867048.

8. Fathi H, Lashtoo Aghaee B, Ebrahimzadeh MA. Antioxidant activity and phenolic contents of Achillea wilhemsii. Pharmacologyonline. 2011;2:942-9.

9. Bashi DS, Fazly Bazzaz BS, Sahebkar A, Karimkhani MM, Ahmadi A. Investigation of optimal extraction, antioxidant, and antimicrobial activities of Achillea biebersteinii and A. wilhelmsii. Pharm Biol. 2012;50(9):1168-76.

10. Asgary S, Naderi GH, Sarrafzadegan N, Mohammadifard N, Mostafavi S, Vakili R. Antihypertensive and antihyperlipidemic effects of Achillea wilhelmsii. Drugs Exp Clin Res.
2000;26(3):89-93.

11. Sharififar F, Pournourmohammadi S, Arabnejad M. Immunomodulatory activity of aqueous extract of Achillea wilhelmsii C. Koch in mice. Indian J Exp Biol. 2009;47(8):668-71.

12. Dadkhah A, Fatemi F, Alipour M, Ghaderi Z, Zolfaghari F, Razdan F. Protective effects of Iranian Achillea wilhelmsii essential oil on acetaminophen-induced oxidative stress in rat liver. Pharm Biol. 2015;53(2):220-7.

13. Ziyyat A, Legssyer A, Mekhfi H, Dassouli A, Serhrouchni M, Benjelloun W. Phytotherapy of hypertension and diabetes in oriental Morocco. J Ethnopharmacol. 1997;58(1):45-54.

14. EL-Hawary S, EL-Shabrawy A, Ezzat S, EL-Shibany F. Gas chromatography-mass spectrometry analysis, hepatoprotective and antioxidant activities of the essential oils of four Libyan herbs. J Med Plants Res. 2013;7(24):1746-53.

15. Rabeh NM, Aboraya AO. Hepatoprotective effect of Dill (Anethum graveolens L.) and fennel (Foeniculum vulgare) oil on hepatotoxic rats. Pakistan J Nutr. 2014;13(6):303-9.

16. Heamalatha S, Swarnalatha S, Divya M, Gandhi Lakshmi R, Ganga Devi A, Gomathi E. Pharmacognostical, pharmacological, investigation on Anethum graveolens Linn: a review. Res J Pharm Biol Chem Sci. 2011;2(4):564-74.

17. Wang Y, Lou L, Wang J, Lu J, Li J, Jia L. Comparative study on Artemisia halodendron Turcz. and its two related plants by GCMS analysis and protective effect against carbon tetrachlorideinduced hepatotoxicity in mice. Nat Prod Res. 2018;32(11):13036.

18. Ornano L, Venditti A, Ballero M, Sanna C, Donno Y, Quassinti L, et al. Essential oil composition and biological activity from Artemisia caerulescens subsp. densiflora (Viv.) Gamisans ex Kerguélen \& Lambinon (Asteraceae), an endemic species in the habitat of La Maddalena Archipelago. Nat Prod Res. 2016;30(16):18029.

19. Guetat A, Al-Ghamdi FA, Osman AK. The genus Artemisia L. in the northern region of Saudi Arabia: essential oil variability and antibacterial activities. Nat Prod Res. 2017;31(5):598-603.

20. Cha JD, Moon SE, Kim HY, Lee JC, Lee KY. The essential oil isolated from Artemisia capillaris prevents LPS-induced production of NO and PGE(2) by inhibiting MAPK-mediated pathways in RAW 264.7 macrophages. Immunol Invest. 2009;38(6):48397.

21. Gao Q, Zhao X, Yin L, Zhang Y, Wang B, Wu X, et al. The essential oil of Artemisia capillaris protects against CCl4-induced liver injury in vivo. Rev Bras Farmacogn. 2016;26(3):369-74.

22. Tomić A, Bozin B, Samojlik I, Milenković M, Mimica-Dukić N, Petrović S. Effects of Athamanta turbith fruit essential oils on CCl4-induced hepatic failure in mice and their antioxidant properties. Phytother Res. 2010;24(5):787-90. 
23. Mehmood F, Shahzadi P, Khan ZUD, Arshad N, Bilal M, Perveen $Z$, et al. In Vivo hepatoprotective and antidiabetic activities of essential oils from Boenninghausenia albiflora (Hook.) reichb. ex heynkh, of Pakistan. MOJ Bioequiv Availab. 2017;4(1):211-4.

24. Blumenthal M, Busse WR. The complete German commission E monographs: therapeutic guide to herbal medicines. Austin: American Botanical Council; 1999. 685 p.

25. Samojlik I, Lakić N, Mimica-Dukić N, Daković-Svajcer K, Bozin B. Antioxidant and hepatoprotective potential of essential oils of coriander (Coriandrum sativum L.) and caraway (Carum carvi L.) (Apiaceae). J Agric Food Chem. 2010;58(15):8848-53.

26. Tung YT, Yen PL, Lin CY, Chang ST. Anti-inflammatory activities of essential oils and their constituents from different provenances of indigenous cinnamon (Cinnamomum osmophloeum) leaves. Pharm Biol. 2010;48(10):1130-6.

27. Tung YT, Huang CC, Ho ST, Kuo YH, Lin CC, Lin CT, et al. Bioactive phytochemicals of leaf essential oils of Cinnamomum osmophloeum prevent lipopolysaccharide/D-galactosamine (LPS/ D-GalN)-induced acute hepatitis in mice. J Agric Food Chem. 2011;59(15):8117-23.

28. Lima FC, Sousa DF, Ferreira JM, Lima Jr RCP, Tomé AR, Cardoso JHL, et al. Croton zehntneri essential oil prevents acetaminophen- induced acute hepatotoxicity in mice. Rec Nat Prod. 2008;2(4):135-40.

29. Uchida NS, Silva-Filho SE, Aguiar RP, Wiirzler LAM, Cardia GFE, Cavalcante HAO, et al. Protective effect of Cymbopogon citratus essential oil in experimental model of acetaminopheninduced liver injury. Am J Chin Med. 2017;45(3):515-32.

30. Silva MR, Ximenes RM, da Costa JG, Leal LK, de Lopes AA, Viana GS. Comparative anticonvulsant activities of the essential oils (EOs) from Cymbopogon winterianus Jowitt and Cymbopogon citratus (DC) Stapf. in mice. Naunyn Schmiedebergs Arch Pharmacol. 2010;381(5):415-26.

31. Ekpenyong CE, Akpan E, Nyoh A. Ethnopharmacology, phytochemistry, and biological activities of Cymbopogon citratus (DC.) Stapf extracts. Chin J Nat Med. 2015;13(5):321-37.

32. Albert-Puleo M. Fennel and anise as estrogenic agents. J Ethnopharmacol. 1980;2(4):337-44.

33. Ozbek H, Uğraş S, Dülger H, Bayram I, Tuncer I, Oztürk G, et al. Hepatoprotective effect of Foeniculum vulgare essential oil. Fitoterapia. 2003;74(3):317-9.

34. Özbek H, Ugras S, Bayram I, Uygan I, Erdogan E, Öztürk A, et al. Hepatoprotective effect of Foeniculum vulgare essential oil: a carbon-tetrachloride induced liver fibrosis model in rats. Scand. J Lab Anim Sci. 2004;31(1):9-17.

35. do Rego JC, Benkiki N, Chosson E, Kabouche Z, Seguin E, Costentin J. Antidepressant-like effect of hyperfoliatin, a polyisoprenylated phloroglucinol derivative from Hypericum perfo- liatum (Clusiaceae) is associated with an inhibition of neuronal monoamines uptake. Eur J Pharmacol. 2007;569(3):197-203.

36. Khan AU, Gilani AH, Najeeb-ur-Rehman. Pharmacological studies on Hypericum perforatum fractions and constituents. Pharm Biol. 2011;49(1):46-56.

37. Süntar IP, Akkol EK, Yilmazer D, Baykal T, Kirmizibekmez H, Alper $\mathrm{M}$, et al. Investigations on the in vivo wound healing potential of Hypericum perforatum L. J Ethnopharmacol. 2010; 127(2):468-77.

38. Dadkhah A, Fatemi F, Farsani ME, Roshanaei K, Alipour M, Aligolzadeh H. Hepatoprotective effects of Iranian Hypericum scabrum essential oils against oxidative stress induced by acetaminophen in rats. Braz Arch Biol Technol. 2014;57(3):340-8.

39. Brandão MG, Pignal M, Romaniuc S, Grael CF, Fagg CW. Useful Brazilian plants listed in the field books of the French naturalist Auguste de Saint-Hilaire (1779-1853). J Ethnopharmacol. 2012;143(2):488-500.

40. Xu DH, Huang YS, Jiang DQ, Yuan K. The essential oils chemical compositions and antimicrobial, antioxidant activities and toxicity of three Hyptis species. Pharm Biol. 2013;51(9):1125-30.

41. Lima GC, Vasconcelos YAG, de Santana Souza MT, Oliveira AS, Bomfim RR, de Albuquerque Júnior RLC, et al. Hepatoprotective effect of essential oils from hyptis crenata in sepsis-induced liver dysfunction. J Med Food. 2018;21(7):709-15.

42. Zaghloul SS, Azzam SM, Eid HH, Hassan HA, Sleem AA. Chemical and biological investigation of essential oil of Oroxylum indicum L. Leaves cultivated in Egypt. Int J Pharmacogn Phytochem Res. 2015;7(3):570-5.

43. Yadav AK, Manika N, Bagchi GD, Gupta MM. Simultaneous determination of flavonoids in Oroxylum indicum by RP-HPLC. Med Chem Res. 2013;22(5):2222-7.

44. Ali M, Chaudhary A, Ramachandran R. New pterocarpans from Oroxylum indicum stem bark. Indian J Chem. 1999;38B:950-2.

45. Pourgholami MH, Majzoob S, Javadi M, Kamalinejad M, Fanaee GH, Sayyah M. The fruit essential oil of Pimpinella anisum exerts anticonvulsant effects in mice. J Ethnopharmacol. 1999; 66(2):211-5.

46. Tabanca N, Ma G, Pasco DS, Bedir E, Kirimer N, Baser KH, et al. Effect of essential oils and isolated compounds from Pimpinella species on NF-kappaB: a target for antiinflammatory therapy. Phytother Res. 2007;21(8):741-5.

47. Andarwulan N, Shetty K. Phenolic content in differentiated tissue cultures of untransformed and Agrobacterium-transformed roots of anise (Pimpinella anisum L.). J Agric Food Chem. 1999; 47(4):1776-80.

48. Jamshidzadeh A, Heidari R, Razmjou M, Karimi F, Moein MR, Farshad O, et al. An in vivo and in vitro investigation on hepatoprotective effects of Pimpinella anisum seed essential oil and ex- 
tracts against carbon tetrachloride-induced toxicity. Iran J Basic Med Sci. 2015;18(2):205-11.

49. Rajopadhye AA, Upadhye AS, Dandge CN, Naik DG. Essential oil from leaf galls on Pistacia chinensis ssp. integerrima: chemical composition, in vitro and in vivo antioxidant and hepatoprotective activity. J Essent Oil Bear Plants. 2016;19(7):1648-59.

50. Ramachandra YL, Shankara BER, Ganapathy PSS, Sundar SR. In-vitro antimicrobial activity of Pistacia integerrima leaf gall extracts. Pharmacophore. 2010;1(2):149-54.

51. Ahmad NS, Waheed A, Farman M, Qayyum A. Analgesic and anti-inflammatory effects of Pistacia integerrima extracts in mice. J Ethnopharmacol. 2010;129(2):250-3.

52. Sanguinetti M, Posteraro B, Romano L, Battaglia F, Lopizzo T, De Carolis E, et al. In vitro activity of Citrus bergamia (bergamot) oil against clinical isolates of dermatophytes. J Antimicrob Chemother. 2007;59(2):305-8.

53. Rasooli A, Fatemi F, Akbarzadeh K, Dini S, Bahremand S. Synergistic protective activity of deuterium depleted water (DDW) and Satureja rechingeri essential oil on hepatic oxidative injuries induced by acetaminophen in rats. J Essent Oil Bear Plants. 2016;19(5):1086-101.

54. Bezić N, Samanić I, Dunkić V, Besendorfer V, Puizina J. Essential oil composition and internal transcribed spacer (ITS) sequence variability of four South-Croatian Satureja species (Lamiaceae). Molecules. 2009;14(3):925-38.

55. Sonboli A, Fakhari A, Kanani MR, Yousefzadi M. Antimicrobial activity, essential oil composition and micromorphology of trichomes of Satureja laxiflora C. Koch from Iran. Z Naturforsch C J Biosci. 2004;59(11-12):777-81.

56. Kandil O, Radwan NM, Hassan AB, Amer AM, el-Banna HA, Amer WM. Extracts and fractions of Thymus capitatus exhibit antimicrobial activities. J Ethnopharmacol. 1994;44(1):19-24.

57. Dob T, Dahmane D, Benabdelkader T, Chelghoum C. Studies on the essential oil composition and antimicrobial activity of Thymus algeriensis Boiss. et Reut. Int J Aromather. 2006;16(2):95100.

58. Van den Broucke CO, Lemli JA. Pharmacological and chemical investigation of thyme liquid extracts. Planta Med. 1981;41(2): 129-35.

59. Dapkevicius A, van Beek TA, Lelyveld GP, van Veldhuizen A, de Groot A, Linssen JP, et al. Isolation and structure elucidation of radical scavengers from Thymus vulgaris leaves. J Nat Prod. 2002;65(6):892-6.

60. Vutyavanich T, Kraisarin T, Ruangsri R. Ginger for nausea and vomiting in pregnancy: randomized, double-masked, placebocontrolled trial. Obstet Gynecol. 2001;97(4):577-82.

61. Fuhrman B, Rosenblat M, Hayek T, Coleman R, Aviram M. Ginger extract consumption reduces plasma cholesterol, inhibits
LDL oxidation and attenuates development of atherosclerosis in atherosclerotic, apolipoprotein E-deficient mice. J Nutr. 2000;130(5):1124-31.

62. Choudhury D, Das A, Bhattacharya A, Chakrabarti G. Aqueous extract of ginger shows antiproliferative activity through disruption of microtubule network of cancer cells. Food Chem Toxicol. 2010;48(10):2872-80.

63. Liu CT, Raghu R, Lin SH, Wang SY, Kuo CH, Tseng YJ, et al. Metabolomics of ginger essential oil against alcoholic fatty liver in mice. J Agric Food Chem. 2013;61(46):11231-40.

64. Matsuda A, Wang Z, Takahashi S, Tokuda T, Miura N, Hasegawa J. Upregulation of mRNA of retinoid binding protein and fatty acid binding protein by cholesterol enriched-diet and effect of ginger on lipid metabolism. Life Sci. 2009;84(25-26):903-7.

65. Li Y, Tran VH, Duke CC, Roufogalis BD. Preventive and protective properties of Zingiber officinale (Ginger) in diabetes mellitus, diabetic complications, and associated lipid and other metabolic disorders: a brief review. Evid Based Complement Alternat Med. 2012;2012:516870.

66. Nakamura Y, Miyamoto M, Murakami A, Ohigashi H, Osawa T, Uchida K. A phase II detoxification enzyme inducer from lemongrass: identification of citral and involvement of electrophilic reaction in the enzyme induction. Biochem Biophys Res Commun. 2003;302(3):593-600.

67. Xia H, Liang W, Song Q, Chen X, Chen X, Hong J. The in vitro study of apoptosis in NB4 cell induced by citral. Cytotechnology. 2013;65(1):49-57.

68. Lai YS, Lee WC, Lin YE, Ho CT, Lu KH, Lin SH, et al. Ginger essential oil ameliorates hepatic injury and lipid accumulation in high fat diet-induced nonalcoholic fatty liver disease. J Agric Food Chem. 2016;64(10):2062-71.

69. Washington MK. Autoimmune liver disease: overlap and outliers. Mod Pathol. 2007;20 Suppl 1:S15-30.

70. Qian T, Herman B, Lemasters JJ. The mitochondrial permeability transition mediates both necrotic and apoptotic death of hepatocytes exposed to Br-A23187. Toxicol Appl Pharmacol. 1999;154(2):117-25.

71. Kon K, Kim JS, Jaeschke H, Lemasters JJ. Mitochondrial permeability transition in acetaminophen-induced necrosis and apoptosis of cultured mouse hepatocytes. Hepatology. 2004; 40(5):1170-9.

72. Santos FA, Rao VS. 1,8-cineol, a food flavoring agent, prevents ethanol-induced gastric injury in rats. Dig Dis Sci. 2001;46(2): 331-7.

73. Santos FA, Rao VS. Antiinflammatory and antinociceptive effects of 1,8-cineole a terpenoid oxide present in many plant essential oils. Phytother Res. 2000;14(4):240-4.

74. Juergens UR, Stöber M, Vetter H. Inhibition of cytokine produc- 
tion and arachidonic acid metabolism by eucalyptol (1.8-cineole) in human blood monocytes in vitro. Eur J Med Res. 1998;3(11): 508-10.

75. Aristatile B, Al-Numair KS, Veeramani C, Pugalendi KV. Effect of carvacrol on hepatic marker enzymes and antioxidant status in D-galactosamine-induced hepatotoxicity in rats. Fundam Clin Pharmacol. 2009;23(6):757-65.

76. Yanishlieva NV, Marinova EM, Gordon MH, Raneva VG. Antioxidant activity and mechanism of action of thymol and carvacrol in two lipid systems. Food Chem. 1999;64(1):59-66.

77. Hajhashemi V, Ghannadi A, Pezeshkian SK. Antinociceptive and anti-inflammatory effects of Satureja hortensis L. extracts and essential oil. J Ethnopharmacol. 2002;82(2-3):83-7.

78. Shelef LA. Antimicrobial effects of spices. J Food Saf. 1984;6(1): 29-44.
79. Sökmen M, Serkedjieva J, Daferera D, Gulluce M, Polissiou M, Tepe $\mathrm{B}$, et al. In vitro antioxidant, antimicrobial, and antiviral activities of the essential oil and various extracts from herbal parts and callus cultures of Origanum acutidens. J Agric Food Chem. 2004;52(11):3309-12.

80. Evangelou A, Kalpouzos G, Karkabounas S, Liasko R, Nonni A, Stefanou D, et al. Dose-related preventive and therapeutic effects of antioxidants-anticarcinogens on experimentally induced malignant tumors in Wistar rats. Cancer Lett. 1997;115(1):10511.

81. Alam K, Nagi MN, Badary OA, Al-Shabanah OA, Al-Rikabi AC, Al-Bekairi AM. The protective action of thymol against carbon tetrachloride hepatotoxicity in mice. Pharmacol Res. 1999;40(2): 159-63. 